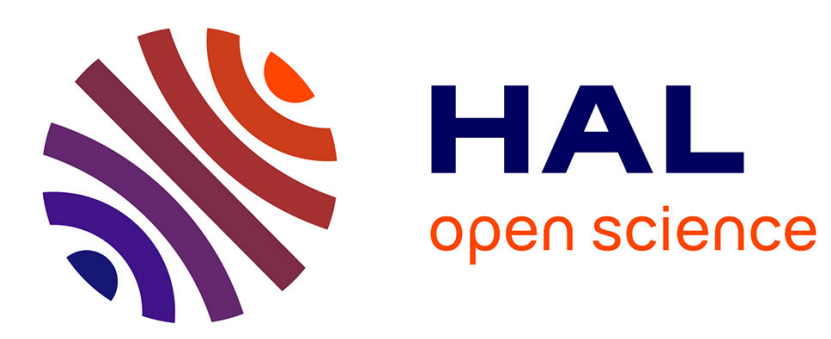

\title{
Globalization, Tax Reform Ideals and Social Policy Financing
}

Steffen Ganghof

\section{To cite this version:}

Steffen Ganghof. Globalization, Tax Reform Ideals and Social Policy Financing. Global Social Policy, 2005, 5 (1), pp.77-95. 10.1177/1468018105050121 . hal-00571778

\section{HAL Id: hal-00571778 \\ https://hal.science/hal-00571778}

Submitted on 1 Mar 2011

HAL is a multi-disciplinary open access archive for the deposit and dissemination of scientific research documents, whether they are published or not. The documents may come from teaching and research institutions in France or abroad, or from public or private research centers.
L'archive ouverte pluridisciplinaire HAL, est destinée au dépôt et à la diffusion de documents scientifiques de niveau recherche, publiés ou non, émanant des établissements d'enseignement et de recherche français ou étrangers, des laboratoires publics ou privés. 


\title{
Globalization, Tax Reform Ideals and Social Policy Financing
}

\author{
STEFFEN GANGHOF \\ Max Planck Institute for Studies of Societies, Cologne, Germany
}

\begin{abstract}
This article compares national income tax reforms during the last 25 years. There were two competing models of income tax reform, 'comprehensive' and 'dual' income taxation, the latter of which was in many ways more successful. The reason lies in the structural constraints policy makers face. While taxation of capital income is very costly, creating incentives to lower marginal tax rates, the high overall tax burden on labour makes it difficult to reduce tax rates on labour incomes. These conflicting pressures point towards separate tax rate schedules for capital and labour, as is characteristic of dual income taxes. The analysis has implications for the role of income taxation in achieving social policy outcomes. Most importantly, while progressive taxation of capital income is constrained by high costs, policy makers willing to separate capital and labour income taxation can use the income tax to reduce the tax burden on low wages.
\end{abstract}

KEYWORDS ideas, income taxation, tax competition, tax mix, tax reform

\section{Introduction}

This article deals with the income tax and its reform. Analysing patterns of income tax reform during the last 25 years - with a focus on Organisation for Economic Co-operation and Development (OECD) countries - provides useful lessons on the potential contribution of the income tax to achieving social policy outcomes and on the role of ideas in policy reform. Income tax policy affects substantive social policy outcomes in two major ways. First, the distribution of the income tax burden adds to the overall redistributive profile of societies. Second, the size of income tax relative to other types of taxes (i.e. the tax mix) may influence policy makers' ability to maintain high social policy expenditures (Kato, 2003; Wilensky, 2002: 430-85). As to the 
role of ideas, the worldwide income tax reform movement is often considered a textbook case of how powerful ideas, supported by particular countries and international organizations, spread around the world (Swank, 1998, 2003; Swank and Steinmo, 2002).

My goal in this article is to throw light on these issues. Within a simple but coherent perspective, I develop the following three claims:

1. Reform Models. The quasi-official, though often implicit, ideal type of the income tax reform wave in OECD countries was that of Comprehensive Income Taxation (CIT), according to which all types of income should be taxed jointly under a common rate schedule. In fact, however, most countries have not approximated this ideal. Instead, a second model emerged in the Nordic countries, Dual Income Taxation (DIT), according to which all types of capital income are taxed at a uniform low and proportional tax rate while labour incomes are subjected to a progressive tax rate schedule. The DIT-model has influenced reform debates in many countries and has been embraced as a useful and consistent model of tax reform by international organizations such as the OECD.

2. Structural Constraints. The success of the DIT-model is rooted in the structural constraints that characterize income taxation. Since some types of capital are too sensitive (i.e. costly-to-tax) to be taxed at high marginal and effective tax rates, the CIT-approach would lead to income taxation at the lowest common denominator. Taken to the extreme, it would lead to a low proportional rate on all income ('Flat Tax'), thus constraining the progressiveness and revenue-raising potential of the income tax.

3. Tax Mixes. High-tax OECD countries have for a long time taken account of these structural constraints by granting large tax privileges to important types of capital income (business profits, capital gains, pension savings, owner-occupied housing), so that high income taxes have not necessarily implied high capital income taxes. Therefore, as exemplified by a country like Denmark, heavy reliance on income taxation has not prevented the building of a large welfare state.

I develop each of these claims in turn. The final section discusses implications for transition and developing countries.

\section{Reform Models: CIT versus DIT}

In the last two decades corporate and personal income tax systems have been restructured both in developed and developing countries (e.g. Boskin and McLure, 1990; Faria, 1995; Ganghof, 2000; Messere, 1993; Messere et al., 2003; Pechman, 1988; Shome, 1999). Basically, marginal tax rates have been cut and tax bases broadened. The recent literature on the political economy 
of these reforms - in advanced OECD countries - strongly emphasizes the importance of policy learning and the diffusion of 'neoliberal' ideas. Policy makers, so the argument goes, learned that high tax rates combined with selective investment incentives are 'ineffective' (Garrett, 1998: 90), leading to inefficient allocation of resources, unfairness and administrative complexity (Steinmo, 2003). Therefore, they made a shift to 'market-conforming' tax policies (Swank, 1998). Swank and Steinmo (2002: 643) even see a shift in the underlying 'policy paradigm' (cf. Hall, 1993) and Kato (2003: 14) speaks of a 'reversal of the ideal of progressive income taxation'. While policy shifts were rooted in the negative experiences of policy makers, tax reforms in powerful countries like the USA and the activities of international organizations triggered and reinforced the worldwide reform wave (Swank, 2003). As Swank (2003: 3) summarizes: '[S]tatutory rate cuts coupled with base-broadening elimination of tax expenditures have become part and parcel of neoliberal economic orthodoxy (e.g., the "Washington consensus").'

While this literature correctly highlights the worldwide shift towards less interventionist and simpler income taxation, it has largely ignored the fact that there were in effect two different models or blueprints for how to make income taxation market-conforming: CIT and DIT. In what follows, I will characterize the two models in more detail and develop the following argument: while the CIT-blueprint fits better into "neoliberal economic orthodoxy' than the DIT-blueprint, the latter has been at least as successful in terms of international diffusion of ideas. ${ }^{1}$ In the following section I then will provide an explanation for this somewhat surprising result.

The 'official' ideal behind many modern income tax systems is that of CIT (see Cnossen, 1988: 263; Messere, 1993: 224, 237-8). The basic idea is to tax all of taxpayers' annual income jointly and equally. No difference should be made between different forms of income, because they all contribute to a taxpayers' ability to pay. Different types of incomes should be taxed jointly under a common and, if desired, progressive rate schedule. The CIT-ideal was never fully implemented in advanced OECD countries, however, as many types of income, particularly capital income, were taxed at preferential tax rates or not taxed at all.

The worldwide tax reform wave started out as an attempt to move realworld income taxes closer to the CIT-ideal. Tax reformers in Great Britain (in 1984), Australia (in 1985), New Zealand (in 1985-6) and the USA (in 1986) were very explicit about this goal (e.g. Conlan et al., 1990: 55-8; Fullerton, 1994; Ganghof, forthcoming-a; Sandford, 1993). One basic idea was to reduce top marginal tax rates to a level at which all types of income could be taxed effectively. Ideally, the CIT-approach also meant to 'integrate' corporate taxation as much as possible into personal income taxation by setting the corporate tax rate equal to the top marginal rate on personal incomes and giving shareholders a credit for taxes already paid at the corporate level (Cnossen, 1988: 263; Head, 1997: 80). 
Not surprisingly, perhaps, the CIT-approach was followed most vigorously and consistently in New Zealand, the country that adopted most of the structural adjustment policies favoured by the International Monetary Foundation (IMF) and other international organizations and was therefore seen by many as the neoliberal model country (cf. Schwartz, 1991, 2000). Within a few years, policy makers cut top marginal tax rates from $66 \%$ to $33 \%$, broadened the income tax base and shifted some of the income tax burden onto a new Goods and Services Tax (Stephens, 1993). Finance Minister Douglas even planned a Flat Tax with a 24\% rate and virtually no tax exemptions but was eventually stopped by Prime Minister Lange (Chapman, 1992). Nevertheless, the low top rate of $33 \%$ allowed policy makers to align it with the corporate tax rate and to include most types of capital income into the tax base.

New Zealand was not a reform leader, however. It was an exception. No other advanced OECD country followed the CIT-model with similar consistency. Top personal income tax rates generally remained at much higher levels than in New Zealand. In 1996, roughly 10 years after the start of the tax reform wave, they averaged $52 \%$ in advanced OECD countries, and none of these countries had a top rate below $40 \% .^{2}$ At the same time, policy makers in these countries remained unwilling to fully integrate all types of capital income into the base of the progressive income tax. Important types of income (e.g. retained corporate profits, pension savings, owner-occupied housing, capital gains) thus continued to benefit from substantial tax privileges (Ganghof, forthcoming-a; OECD, 2000: 123-65).

It is tempting to explain these deviations from the CIT-ideal simply as such: varying degrees of deviation caused by variations in party ideology, constitutional structures, interest group pressure, etc. This would be wrong, however, because policy makers in the Nordic countries actually developed a competing blueprint of income tax reform: the DIT (Cnossen, 1999; Sørensen, 1993, 1998a). What this model shares with the CIT-model is the strong emphasis on market-conforming capital income taxation. Both models aim at taxing all types of capital at the same marginal and average rates in order not to intervene into the structure of savings and investment decisions and to reduce tax avoidance. However, the DIT-model does not extend this logic of equal and joint taxation to labour incomes. Instead, capital and labour taxation is separated systematically; while capital income is taxed at a low, uniform and proportional tax rate (between $25 \%$ and $30 \%$ in the Nordic countries), labour income is taxed progressively at a higher top marginal rate (typically between $50 \%$ and $60 \%$ ).

The DIT-model originated in Denmark in the early 1980s, but similar ideas were also discussed in Norway during this period (Norges Offentlige Utredninger [NOU], 1984; Sørensen, 1993: 359-60). The model's development owed much to the peculiarities of income taxation in the Nordic countries. To understand this point it is useful to take a closer look at the 
taxation of 'owner-occupied housing', one major area of social policy tax expenditures (Ervik, 2000; Howard, 1997). An ideal Comprehensive Income Tax would allow financing costs (interest payments) to be deducted from the tax base while at the same time including the implicit rent earned by owneroccupiers into the tax base. However, policy makers in virtually all OECD countries were unwilling to fully include this implicit rent into the tax base. Many countries therefore also restricted or disallowed interest deductibility. In the Nordic countries, however, policy makers continued to allow interest deductibility while taxing the returns to housing investments lowly or not at all (Sørensen, 1998b). As a result, the state subsidized private debt up to the top marginal income tax rate, which led to inefficient allocation of resources, a low savings ratio of households, low or even negative revenue from taxing personal capital income and low or absent effective income tax progressiveness. The dual income tax provided an elegant solution to these problems. By taxing all capital income at a low and proportional rate, policy makers not only found it easier to include more capital income into the income tax base (including the implicit rent earned by owner-occupiers) but also achieved an immediate reduction in the tax rate against which interest expenses could be deducted. This mitigated all of the problems discussed and increased tax revenue. $^{3}$

Of course, the same result could have been achieved under the CIT-model, if Nordic policy makers had been willing to tax all income (including labour income) at the same low and proportional tax rate as sensitive capital income. Yet they were not; they continued to prefer progressive taxation of labour incomes with higher top marginal rates. The price to pay was a higher degree of administrative complexity. Techniques had to be found to separate the capital and labour income of small businesses, which would otherwise have both incentive and opportunity to 'transform' highly taxed labour income into lowly taxed capital income (Hagen and Sørensen, 1998).

Sweden, Norway and Finland implemented the dual income tax model in different forms and with varying degrees of consistency (Cnossen, 1999). Denmark, by contrast, moved away from the DIT-model and towards a more differentiated income tax in the 1990s (Ganghof, forthcoming-a). The country that implemented the DIT-model most consistently was Norway (Van den Noord, 2000: 6). It became '[t]he leading nation in the field' (Mutén, 1996: 19), comparable to New Zealand with respect to the CIT-approach. Yet just as New Zealand did not actually achieve the CIT-ideal, Norway did of course not implement the DIT-model perfectly. Most notably, owneroccupied housing as well as private and occupational pension savings continued to receive preferential tax treatment (Ervik, 2000: 187-201, 225-48; Holmøy and Vennemo, 1995).

Although the DIT-blueprint was not (initially) propagated by international organizations or large and powerful countries, it proved to be a highly influential idea. After it had spread in the Nordic countries, it heavily 
influenced policy debates all over the OECD world and was copied or adapted by many countries. Italy and the Netherlands developed and implemented their own versions of the DIT-model (Bordignon et al., 2001; Cnossen and Bovenberg, 2001). Other countries like Austria did not adopt the model entirely but took far-reaching steps towards it (Genser, 1996). The model was increasingly taken seriously by mainstream economists and international organizations. The OECD began to feature the DIT-model as a consistent approach to income tax reform with unique advantages, especially in open economies (Messere et al., 2003: 115-26; OECD, 2001). In many country studies, too, the OECD highlighted the DIT as an attractive reform model, even for low-tax economies like Japan and for countries, like New Zealand, in which the revitalization of the CIT-ideal had begun (Dalsgaard and Kawagoe, 2000: 32; OECD, 2000: 163-5). The DIT-blueprint was also embraced by top level advisory councils and reform commissions in Germany and Japan, and recent reforms in Germany and the USA were partly inspired by the model (Ganghof, forthcoming-a; Morinobu, 2004).

In sum, then, the not so neoliberal blueprint of DIT seems at least as successful an idea as the blueprint of CIT; Norway (together with Sweden and Finland) was at least as influential a model as New Zealand. In fact, the DITmodel was in many ways more successful than the DIT-ideal. Although its development owed much to the peculiarities of Nordic income taxation and was not (initially) endorsed by international organizations or powerful countries, it spread around the OECD world. The next section sketches a systematic explanation of this somewhat puzzling result.

\section{Structural Constraints: What Makes the DIT-model Attractive?}

Ideas are to a large extent endogenous to material conditions. The success of particular reform blueprints depends on how well they match the structural constraints and incentives policy makers face. To explain the success of different reform ideas, therefore, one needs a systematic account of constraints and incentives as a baseline. ${ }^{4}$ In this section, I sketch such an account and present some empirical evidence supporting it. ${ }^{5}$

In a nutshell, many policy makers in OECD countries have found the DITmodel attractive because they face both structural incentives to strongly reduce the top marginal tax rate on capital and structural constraints in reducing the top marginal tax rate on labour. With respect to capital income taxation, the problem is that there are many types of capital income that are considered too 'sensitive', i.e. costly-to-tax, to be taxed highly. The relevant costs can be economic (inefficiency and thus reduced growth), administrative (red tape) or political (voter resentment). Some important examples have already been mentioned. Taxing owner-occupied housing tends to be politically explosive (Sørensen, 1998a), taxing certain types of business investment may lead to particularly high economic costs (De Long and 
Summers, 1991), and taxing capital gains is administratively difficult and costly (Slemrod, 2000). Policy makers thus have strong reasons to tax these and other types of capital income at moderate tax rates. Yet if they strive for 'market-conforming' capital income taxation, they also have to tax all other types of capital income at the same moderate rates. In sum, the high costs of taxing capital income combined with the goal of market-conformity and administrative simplicity strongly suggest a low uniform proportional tax rate on all types of capital income (Slemrod, 1990).

Yet why should a low and preferably proportional tax rate not also be extended to labour income, as the CIT-model would imply? Proponents of this solution emphasize that it would further simplify income taxation and that 'indirect' progressiveness could still be maintained by way of a sizeable basic tax allowance (i.e. a zero tax rate for income below a certain threshold). Why have not more countries pursued this 'Flat Tax' approach?

The answer, I suggest, lies in the high overall tax burden on wages that characterizes high-tax countries. The higher the overall tax burden on wages, the higher top personal income tax rates have to be in order to achieve even a moderate amount of progressiveness in overall labour taxation. This structural constraint on reducing top personal income tax rates (on labour income) plays out in two different ways, depending on the importance of income taxation within a country's tax mix.

1. In a country like Denmark, where a high total tax burden goes together with a high income tax burden (almost 30\% of Gross Domestic Product [GDP]), a revenue-neutral switch to an indirectly progressive CIT is simply unfeasible. If most capital income were to be included into the income tax base, the tax rate could probably not be higher than 25\% (Det Økonomiske Råd, 2001) and cutting the top rate on wages to this low a level would imply major revenue losses, which would be even greater if a substantial basic tax allowance were to be maintained.

2. In a country like Austria, where a high total tax burden goes together with a moderate income tax burden (roughly 13\% of GDP), an indirectly progressive income tax with $25 \%$ rate would be feasible, but only because a large part of labour 'taxation' takes the form of social security contributions (payroll taxes) and general consumption taxes. Since this additional labour taxation is proportional and in part regressive, the progressive income tax tends to assume a 'progressiveness adjustment' function. Policy makers have incentives to maintain progressive income taxes on wages, even if this means separation of labour and capital taxation.

We can visualize the effect of structural constraints quantitatively by focusing on corporate tax rates (on retained profits) and top personal income tax rates. As noted in the previous section, these two rates should be equal under a CIT- 
approach in order to avoid economic distortions, simplify administration and prevent harmful tax avoidance through the choice of corporate or noncorporate legal form (cf. Head, 1997). In line with this view, international institutions like the IMF have 'frequently recommended that personal and corporate income taxes have the same top marginal rate' (Stotsky, 1995: 282). Or, at least, they should 'not differ materially' (Tanzi and Zee, 2000: 310). Achieving an alignment between the two rates is difficult, however, because retained corporate profits are clearly 'sensitive' capital income and because corporate tax rates have been subject to increasing competitive pressure. Recent studies show that corporate tax rates do play a role in the location of Foreign Direct Investment (FDI), especially profitable investment (e.g. Devereux and Griffith, 1998, 2003). In addition, high corporate tax rates provide strong incentives for multinationals to shift their profits into low-tax jurisdictions, e.g. by manipulating prices in intra-company trade ('transfer prices') (Hines, 1999). As a result, there has been a downward spiral in corporate tax rates since the mid-1980s, as countries have tried to undercut the tax rates of their competitors and important capital exporters like the USA.

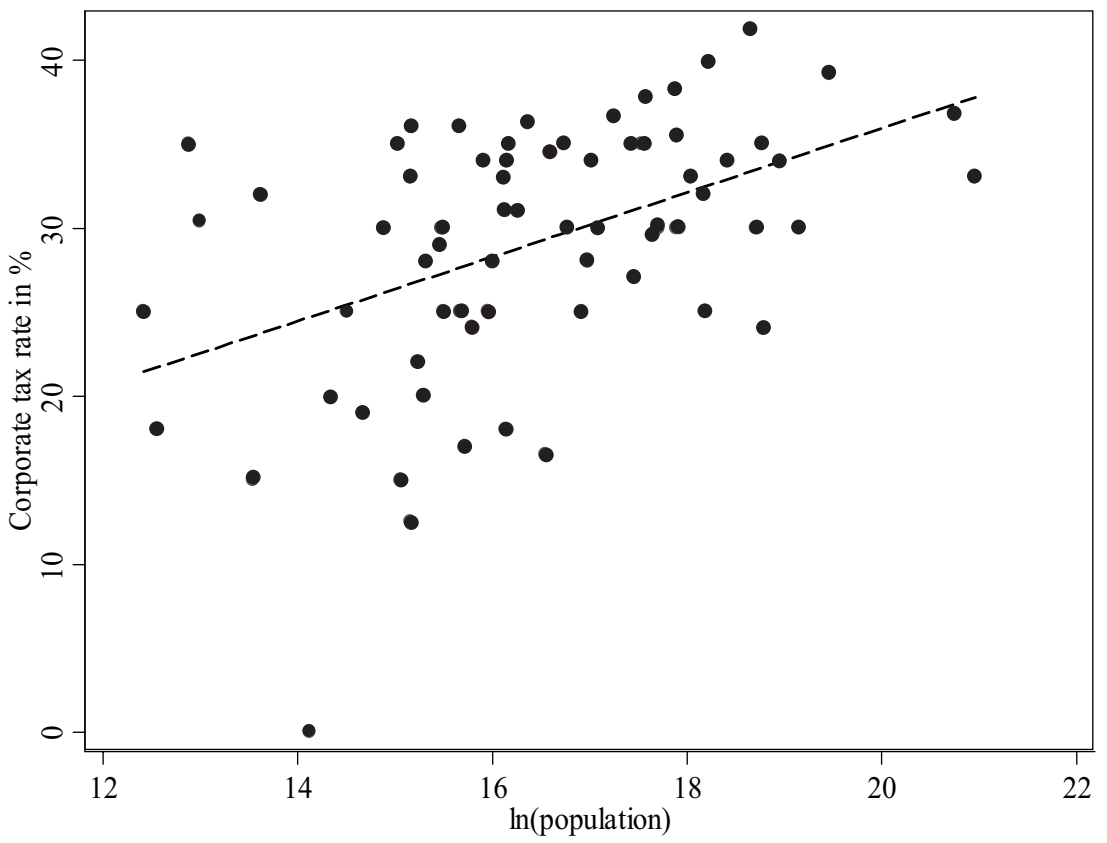

F I GURE I Corporate tax rates and country size, 2003

Notes: Corporate tax rates include sub-national business taxes and surcharges. The countries included are those covered by the 'KPMG Corporate Tax Survey' plus the remaining countries of the enlarged European Union.

Sources: Data on population comes from World Bank (2003). Data on corporate tax rate comes from BMF (2003), KPMG (2003) and national sources. 
Proponents of 'ideational' explanations of corporate tax cuts may doubt the importance of tax competition, seeing globalization as a 'bogey-man' (Steinmo, 2003: 230) rather than a contributing cause. Yet there is clear quantitative evidence for the role of tax competition. The economic theory of tax competition predicts that if two countries of unequal size compete with each other for mobile tax bases (capital), the smaller country will in equilibrium have a lower tax rate (e.g. Bucovetsky, 1991). In a small country with a small existing capital stock, a tax cut does not lead to large revenue losses. At the same time, relatively high revenue can be expected due to the inflow of foreign capital. Hence, if tax competition has played a role in the setting of corporate tax rates, we would expect an increasingly positive association between corporate tax rates and country size. This is exactly what we see. In a panel analysis for advanced OECD countries, Ganghof (2004) shows that such a relationship had been absent before the mid-1980s but developed afterwards. Figure 1 provides a snapshot of the situation in 2003 for a larger sample of 74 countries - those countries covered by the 'KPMG Corporate Tax Survey' (Klynveld, Peat, Marwick und Goerdeler [KPMG], 2003). The correlation between country size (natural logarithm of population) and corporate tax rates shows that smaller countries have lower corporate tax rates than larger countries. While many large countries still have corporate tax rates of around $40 \%$, many small countries have moved to corporate tax rates of $25 \%$ or lower. The new European Union (EU) member state Estonia even has a zero tax rate on retained corporate profits.

What tax competition means for the feasibility of the CIT-ideal, especially in small countries, should be obvious. If policy makers seriously tried to align the top rate on personal income with a competitive corporate tax rate, this would typically lead to significant revenue losses or reduced tax progressiveness or both. This is most obvious for the special case of Estonia. If the top personal rate were reduced to zero, the revenue from income taxation, roughly one fourth of Estonia's total tax revenue (Eurostat, 2004: 154) would vanish. While this case is extreme, there are many examples of small countries in which an alignment between the corporate rate and the top personal rate is virtually impossible. One example, Denmark, has already been mentioned. Another one is Ireland, which recently moved to a corporate rate of $12.5 \%$. If the top personal rate were also reduced to this level, income tax revenue $(13 \%$ to $14 \%$ of GDP) could not be maintained. Hence, the Irish top personal rate was cut significantly over the last couple of years but nevertheless 'only' to $42 \%$ (cf. Hardiman, 2001).

It is not surprising, therefore, that top personal income tax rates are not systematically related to country size in advanced OECD countries. Instead, these rates are systematically associated with the total tax burden, as suggested by theoretical argument sketched above (cf. Ganghof, 2004). Figure 2 shows this for a sample of 20 countries by plotting, for the year 2003, corporate and top personal tax rates against total tax revenue as a percentage of GDP. The 


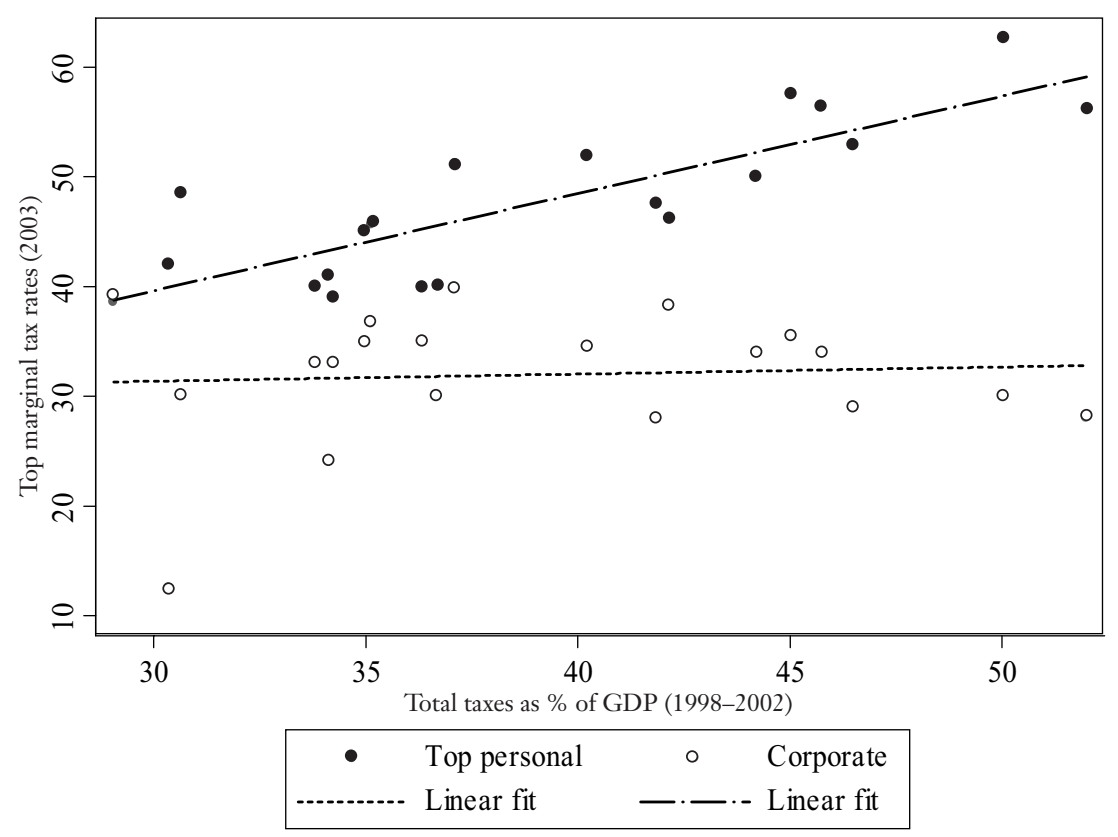

FIG URE 2 Top marginal income tax rates and total tax burden, 2003

Notes: Tax rates include sub-national taxes and surcharges. The countries included are the 'old' European Union countries (excluding Luxembourg) plus Australia, Canada, New Zealand, Norway, Switzerland and the US.

Sources: On the sources of corporate tax rate data see Figure 1. Data on top personal income tax rates comes from BMF (2003) and national sources. Data on total tax burdens comes from OECD (2004).

higher the total tax burden, the larger is the gap between the corporate tax rate and the top personal income tax rate (on wages) and the more difficult it becomes to approximate the ideal of CIT. Hence, if policy makers in high-tax countries, especially small ones, aim at 'market-conforming' capital income taxation, the DIT-model may be better suited to achieve this goal than the CIT-model. ${ }^{6}$ As the OECD (2000: 165) puts it: 'a dual income tax may be the better [reform] option, since it would not impose the same straight-jacket on the top personal rate (on wage income)'.

While Figures 1 and 2 aptly visualize the difficulties of the CIT-model and the advantages of the DIT-model, it should be re-emphasized that the problem of capital income taxation is not only or even mainly tax competition. As noted above, there are plenty of reasons why policy makers may consider certain types of capital income as 'sensitive' and many of them are domestic. In fact, the Nordic welfare states, among others, have managed to adapt to increased economic internationalization and increase capital income tax revenue because the average effective tax burden on capital income had traditionally been rather low in these countries. 


\section{Tax Mixes: Are 'Regressive Taxes' Conducive to Social Policy Expenditures?}

The structural account of income tax policy sketched in the previous section cannot only be used to explain the development and success of reform ideas but also throws light on recent arguments about the historical relationship between tax mixes and social policy expenditures. ${ }^{7}$ Both Wilensky (2002: $430-85$ ) and Kato (2003) suggest (mainly for advanced OECD countries) that 'regressive' tax mixes - i.e. a large reliance on social security contributions (payroll taxes) and general consumption taxes - were conducive to building and maintaining large tax/welfare states. While the two arguments partly differ in their details and both rely on several causal mechanisms, they do share one important assumption which is clearly stated by Wilensky (2002): income and property taxes, but not consumption and payroll taxes, imply a heavy tax burden on capital and are therefore a 'drag on economic growth' (Wilensky, 2002: 392; see also Kato, 2003: 199). Therefore, a large reliance on income and property taxes reduces the efficiency of the overall tax system and thus makes it more difficult to build up and maintain a large tax burden.

This argument is similar to the one sketched in the previous section in that it highlights the strong economic constraints on capital income taxation. In both cases the assumption is that the tax burden associated with high public (social policy) expenditures has to be shouldered largely by labour incomes (cf. Lindert, 2004; Summers et al., 1993). However, neither Wilensky nor Kato appreciate the fact that high income taxation does not necessarily imply high capital income taxation. As argued, high-tax OECD countries have a long tradition of limiting the tax burden on capital income, either by removing it from the income tax base or by subjecting it to lower tax rates than labour income. In other words, the tax base of real-world income taxes can lie somewhere on the continuum between a CIT, implying equal tax burdens on capital and labour incomes, and a pure wage tax that completely exempts capital income. If the tax base of the progressive income tax is variable in this way, however, the structural constraints in capital income taxation do not imply a relationship between tax mixes and the size of the tax/welfare state. For it is possible to determine the levels of income taxation and capital income taxation independently within relatively broad limits.

Denmark provides an excellent example (Ganghof, forthcoming-b). As noted, Denmark has a tradition of financing social policy expenditures with taxes rather than social security contributions, which has led to a very large income tax burden. While Danish policy maker's large reliance on the income tax did not prevent them from building one of the world's largest welfare states, the growth of the income tax was predicated on large tax privileges for capital income. In fact, estimates suggest that the Danish income tax had traditionally been closer to a pure wage tax than to a comprehensive income tax. Sørensen (1988) estimated that in the mid-1980s the taxation of personal 
capital income led to a revenue loss of $1.6 \%$ of GDP, which was roughly balanced by the positive revenue generated by corporate taxation. Hence, virtually the entire income and profit tax burden fell on wages. As a result of the tax reforms of the 1980s and 1990s the capital income tax burden increased, but it is still much lower than the tax burden on labour. For 2002, Eurostat (2004: 146) puts the 'implicit tax rate' on capital income (including self-employed labour) at $16.1 \%$, and that on employed labour at $39.9 \%$. Estimates for a country like France are very similar (19.6\% and 41.8\%, respectively), even though its income tax is relatively small (around 11\% of GDP) (Eurostat, 2004: 164). Hence, the main difference between the two countries seems to lie in the institutional form labour taxation takes - with social security contributions being much more important in France - but not in the taxation of capital income.

It may thus be argued that tax mixes are of rather limited relevance to the size of the tax/welfare state and that high income taxes are actually beneficial in high-tax countries. Social security contributions - seen as 'taxes' - are often regressive because they do not have a basic tax allowance, which reduces the relative tax burden on low-income earners, but do have ceilings on contributions, which reduce the relative tax burden on high-income earners. Hence, to the extent that the negative incentive effects of high labour taxes are particularly severe at the lower end of the wage scale, a greater reliance on income taxation may make the overall tax structure more efficient.

One caveat should be noted, however. While globalization has not led to a downward trend in capital income tax revenue - for reasons explained - the strong competitive pressure on statutory corporate tax rates may provide a major challenge for the income tax. Market-conforming capital income taxation requires equal tax rates on all types of capital income and the corporate tax rate is the most obvious and adequate benchmark in this respect (Cnossen, 1999). At the same time, even under the DIT-approach policy makers face strong incentives to keep the gap between the capital income tax rate and the top rate on labour incomes as small as possible in order to reduce tax avoidance, administrative complexity and voter discontent about the discrimination against wages. As a result, corporate tax competition may indirectly 'pull down' personal income tax rates. Elsewhere, I present both qualitative and quantitative evidence that this kind of spill-over effect of corporate tax competition is already visible but has so far been rather moderate (Ganghof, 2004, forthcoming-a; Ganghof and Eccleston, 2004).

\section{Conclusion: The Future of the Income Tax}

There is no need to reiterate the three central claims elaborated in this article and summarized in the introduction. I rather want to use this concluding section to develop two main implications of my analysis for countries outside of the set of 'advanced' OECD countries. 
First, there is no reason to be overly pessimistic about the role income taxation can play in financing social policy expenditures. Policy makers can raise significant amounts of revenue with income taxes. In order to do so, however, they may have to differentiate between the taxation of capital and labour incomes. The DIT-model provides a coherent model for achieving this differentiation in a 'market-conforming' way. The advantage of the DITmodel is that it allows policy makers to combine moderate and efficient taxation of capital income with some degree of progressiveness in labour income taxation.

This point seems important because transition and developing countries are typically characterized by low income taxes and tax experts argue that in many of these countries income taxes should be structurally reformed and increased (e.g. Shome, 1999). ${ }^{8}$ If tax policy makers base structural reforms on the CITmodel, however, they may freeze the low existing levels of income taxation. Consider the example of the Slovak Republic, a new EU member state, which recently decided to take advantage of its low income tax burden (around 7\% of GDP; Eurostat, 2004: 213) by moving to a flat personal income tax rate of $19 \%$, aligned with the corporate tax rate. By doing so, the country replaced New Zealand as the 'neoliberal' model in tax policy and is envied by radical tax reformers all over the world. What my analysis has shown is that there is no need for other transition or developing countries to follow Slovakia's example, even if they have a strong preference for competitive and 'marketconforming' income taxation. Slovenia, for example, recently reduced its corporate tax rate to $25 \%$ while leaving the top personal rate at an unchanged $50 \% .{ }^{9}$ DIT provides a model for how to combine such a large tax rate gap with efficient capital income taxation, thereby giving policy makers the option of combining structural tax reform with an increase of the income tax burden.

The second implication of my analysis modifies the first. While there is no need to be fixated on the CIT-model, it is nevertheless true that a gap between corporate and top personal income tax rates creates problems even under a DIT. In the Nordic countries, for instance, there has been more or less constant debate about reducing the tax rate gap between capital and labour taxation in order to reduce tax avoidance and simplify administration. Hence, if tax competition continues to drive down corporate tax rates, it may indeed become increasingly difficult to maintain high top personal income tax rates on labour even under the DIT-approach. Since income taxes are comparatively difficult to administer, this may lead developing countries to opt for the CIT (Flat Tax) approach rather than the DIT-model, especially if administrative capacity is low. If this happens, the income tax cannot assume a 'progressiveness adjustment' function within the overall tax system and it will therefore be important to explore ways to distribute the burden of other taxes or contributions more broadly, fairly and efficiently. For example, a number of OECD countries recently made social security contributions more akin to income taxes by removing ceilings on social security contributions, 
reducing contributions for certain classes of employees (women, the young, part-time workers) or introducing a basic personal allowance (Messere et al., 2003: 21).

This point leads me finally to emphasize what might be the most basic lesson of the analysis. The structure of particular taxes, the mix between different taxes and the overall level of taxation form a 'system' or 'equilibrium', in which each part is dependent upon the others (cf. Hettich and Winer, 1999). Therefore, both empirical studies of taxation and normative debates about tax reform and distributive profiles of tax systems should avoid looking at particular taxes in isolation. To understand the role of ideas in income tax reform and form expectations about the future of the income tax, it is necessary to understand both its internal logic and the way in which it is embedded within the overall tax system.

NOTES

1. For a more complete and detailed conceptual discussion of different models of income taxation see Ganghof (2004; forthcoming-a).

2. Unweighted average for 21 advanced OECD countries. See notes to Figure 1 for data definitions and sources.

3. In fact, the cut in tax subsidies created severe strains in the housing markets of the Nordic countries, which also added to macroeconomic problems. The cut was capitalized in prices and thus led to a drop in the value of real estate. A considerable number of homeowners could no longer cover their mortgage with the market value of their real estate and went bankrupt (e.g. Huber and Stephens, 1998; Nannestad and Green-Pedersen, forthcoming).

4. This view, though far from new, has recently been highlighted and elaborated in the political science literature on ideas in foreign policy (e.g. Brooks and Wohlforth, 2000, 2002; Goldstein and Keohane, 1993).

5. This section draws on Ganghof (2004; forthcoming-a).

6. Policy makers may of course deliberately reject both models of income tax reform as too radical, as they did in Denmark in the 1990s. If they do, however, they have to sacrifice the goal of market-conforming capital income taxation. See Ganghof (forthcoming-a) for a more detailed exploration of the resulting 'trilemma' of income taxation.

7. The following draws on Ganghof (forthcoming-b).

8. Structural reforms of income taxes are perhaps easiest when relatively few people are paying it, as there are fewer vested interests in the system (Heady, 2002: 7).

9. In line with my theoretical argument and the pattern visible in Figure 2, the Slovak Republic has one of the lowest total tax burdens of the new European Union member states (33\% in 2002), Slovenia one of the highest $(39.8 \%$ ) (Eurostat, 2004: 210, 213).

REFERENCES

BMF (Bundesministerium der Finanzen [German Ministry of Finance]) (2003) Die wichtigsten Steuern im internationalen Vergleich. Bonn: BMF. 
Bordignon, M., Giannini, S. and Panteghini, P. (2001) 'Reforming Business Taxation: Lessons from Italy?', International Tax and Public Finance 8(2): 191-210.

Boskin, M.J. and McLure, C.J. (eds) (1990) World Tax Reform: Case Studies of Developed and Developing Countries. San Francisco, CA: ICS Press.

Brooks, S.G. and Wohlforth, W.C. (2000) 'Power, Globalization and the End of the Cold War: Reevaluation a Landmark Case for Ideas', International Security 25(3): $5-53$.

Brooks, S.G. and Wohlforth, W.C. (2002) 'From Old Thinking to New Thinking in Qualitative Research', International Security 26(4): 93-111.

Bucovetsky, S. (1991) ‘Asymmetric Tax Competition', Fournal of Urban Economics 30(2): $167-81$.

Chapman, R. (1992) 'A Political Culture Under Pressure: The Struggle to Preserve a Progressive Tax Base for Welfare and the Positive State', Political Science 44(1): 1-27.

Cnossen, S. (1988) 'Overview', in J.A. Pechman (ed.) World Tax Reform: A Progress Report (pp. 261-8). Washington, DC: The Brookings Institution.

Cnossen, S. (1999) 'Taxing Capital Income in the Nordic Countries: A Model for the European Union?', Finanzarchiv 56(1): 18-50.

Cnossen, S. and Bovenberg, L. (2001) 'Fundamental Tax Reform in the Netherlands', International Tax and Public Finance 8(4): 467-80.

Conlan, T.J., Wrightson, M.T. and Beam, D.R. (1990) Taxing Choices: The Politics of Tax Reform. Washington, DC: CQ Press.

Dalsgaard, T. and Kawagoe, M. (2000) 'The Tax System in Japan: A Need for Comprehensive Reform', Economics Department Working Papers No. 231, OECD, Paris.

De Long, J.B. and Summers, L.H. (1991) 'Equipment Investment and Economic Growth', Quarterly Fournal of Economics 106(2): 445-502.

Det Økonomiske Råd (2001) 'Danish Economy: Spring 2001 (English Summary)', accessed 12 October 2002: http://www.dors.dk/rapp/dors086.htm

Devereux, M.P. and Griffith, R. (1998) 'Taxes and the Location of Production: Evidence from a Panel of US Multinationals', Fournal of Public Economics 68(2): 335-67.

Devereux, M.P. and Griffith, R. (2003) 'Evaluating Tax Policy for Location Decisions', International Tax and Public Finance 20(1): 107-26.

Ervik, R. (2000) 'The Hidden Welfare State in Comparative Perspective: Tax Expenditures and Social Policy in Eight Countries', PhD thesis, Department of Comparative Politics, University of Bergen, Norway.

Eurostat (2004) Structures of the Taxation System in the European Union: Data 1995-2002. Luxembourg: Eurostat.

Faria, A.G.A. (1995) 'Reform in Market Economies and Economies in Transition: Principles and Experience', in P. Shome (ed.) Tax Policy Handbook (pp. 275-8). Washington, DC: International Monetary Fund.

Fullerton, D. (1994) 'Tax Policy', in M. Feldstein (ed.) American Economic Policy in the 1980 s (pp. 165-208). Chicago, IL: University of Chicago Press.

Ganghof, S. (2000) 'Adjusting National Tax Policy to Economic Internationalization: Strategies and Outcomes', in F.W. Scharpf and V.A. Schmidt (eds) Welfare and Work in the Open Economy. Volume II: Diverse Responses to Common Challenges (pp. 597-645). Oxford: Oxford University Press.

Ganghof, S. (2004) 'Progressive Income Taxation in Advanced OECD Countries. Revisiting the Structural Dependence of the State on Capital', paper presented at the Annual Meeting of the American Political Science Association Chicago, 1-5 September. 
Ganghof, S. (forthcoming-a) Parties, Power and Progressivity: The Political Economy of Income Taxation in Open States. Colchester: ECPR Press.

Ganghof, S. (forthcoming-b) 'Tax Mixes and the Welfare State: The Danish Puzzle in Comparative Perspective', Discussion Paper, Max Planck Insitute for the Study of Societies, Cologne.

Ganghof, S. and Eccleston, R. (2004) 'Globalization and the Dilemmas of Income Taxation in Australia', Australian fournal of Political Science 39(4): 519-34.

Garrett, G. (1998) 'Shrinking States? Globalization and National Autonomy in the OECD', Oxford Development Studies 26(1): 71-97.

Genser, B. (1996) 'Austria's Steps towards a Dual Income Tax', in L. Mutén, P.B. Sørensen, K.P. Hagen and B. Genser (eds) Towards a Dual Income Tax? (pp. 69-89). London: Kluwer Lax International.

Goldstein, J. and Keohane, R.O. (1993) 'Ideas and Foreign Policy: An Analytical Framework', in J. Goldstein and R.O. Keohane (eds) Ideas and Foreign Policy. Beliefs, Institutions, and Political Change (pp. 3-30). Ithaca, NY: Cornell University Press.

Hagen, K.P. and Sørensen, P.B. (1998) 'Taxation of Income from Small Businesses: Taxation Principles and Tax Reforms in the Nordic Countries', in P.B. Sørensen (ed.) Tax Policy in the Nordic Countries (pp. 28-71). Houndmills: Macmillan.

Hall, P.A. (1993) 'Policy Paradigms, Social Learning, and the State: The Case of Economic Policymaking in Britain', Comparative Politics 25(3): 275-96.

Hardiman, N. (2001) 'Taxing the Poor: The Politics of Income Taxation in Ireland', Policy Studies fournal 28(4): 815-42.

Head, J.G. (1997) 'Company Tax Structure and Company Tax Incidence', International Tax and Public Finance 4(1): 61-100.

Heady, C. (2002) 'Tax Policy in Developing Countries: What Can Be Learned from OECD Experience?', paper presented at the Seminar for Taxing Perspectives: A Democratic Approach to Public Finance in Developing Countries at the Institute of Development Studies, University of Sussex, 28-9 October.

Hettich, W. and Winer, S.L. (1999) Democratic Choice and Taxation: A Theoretical and Empirical Analysis. Cambridge: Cambridge University Press.

Hines, J.R., Jr (1999) 'Lessons form Behavioral Responses to International Taxation', National Tax fournal 52(2): 305-22.

Holmøy, E. and Vennemo, H. (1995) 'A General Equilibrium Assessment of a Suggested Reform in Capital Income Taxation', Fournal of Policy Modeling 17(6): 531-56.

Howard, C. (1997) The Hidden Welfare State: Tax Expenditures and Social Policy in the United States. Princeton, NJ: Princeton University Press.

Huber, E. and Stephens, J.D. (1998) 'Internationalization and the Social Democratic Model: Crisis and Future Prospects', Comparative Political Studies 31(3): 353-97.

Kato, J. (2003) Regressive Taxation and the Welfare State: Path Dependence and Policy Diffusion. Cambridge: Cambridge University Press.

KPMG (2003) 'KPMG's Corporate Tax Rate Survey - January 2003', accessed 13 February 2004, http://www.in.kpmg.com/ctrs.html

Lindert, P.H. (2004) Growing Public. Volume One: The Story. Cambridge: Cambridge University Press.

Messere, K. (1993) Tax Policy Choices in OECD Countries. Amsterdam: IBFD Publications BV.

Messere, K., De Kam, F. and Heady, C. (2003) Tax Policy: Theory and Practice in OECD Countries. Oxford: Oxford University Press. 
Morinobu, S. (2004) 'Capital Income Taxation and the Dual Income Tax', accessed 30 August 2004: http://www.mof.go.jp/jouhou/soken/kenkyu/ron097.pdf

Mutén, L. (1996) 'Dual Income Taxation: Swedish Experience', in L. Mutén, B.P. Sørensen, K.P. Hagen and B. Genser (eds) Towards a Dual Income Tax? (pp. 7-21). London: Kluwer Law International.

Nannestad, P. and Green-Pedersen, C. (forthcoming) 'Keeping the Bumblebee Flying: Economic Policy in the Welfare State of Denmark, 1973-99', in E. Albäk, P. Eliason and A.S. Norgaard (eds) Managing the Danish Welfare State under Pressure: Towards a Theory of the Dilemmas of the Welfare State. Aarhus: Aarhus University Press.

NOU (Norges Offentlige Utredninger) (1984) Personbeskatning. Skattekommisjonens Vurderinger av og Forslag til System for Personbeskatning [Reports of the Government Commissions]. Oslo.

OECD (2000) OECD Economic Surveys: New Zealand. Paris: OECD.

OECD (2001) Tax and the Economy: A Comparative Assessment of OECD Countries. Paris: OECD.

OECD (2004) Statistical Compendium. Paris: OECD.

Pechman, J.A. (ed.) (1988) World Tax Reform: A Progress Report. Washington, DC: Brookings.

Sandford, C. (1993) Successful Tax Reform: Lessons from an Analysis of Tax Reform in Six Countries. Fersfield, UK: Fiscal Publications.

Schwartz, H. (1991) 'Can Orthodox Stabilization and Adjustment Work? Lessons from New Zealand 1984-90', International Organization 45(2): 221-56.

Schwartz, H. (2000) 'Internationalization and Two Liberal Welfare States: Australia and New Zealand', in F.W. Scharpf and V.A. Schmidt (eds) Welfare and Work in the Open Economy. Diverse Responses to Common Challenges (pp. 69-130). Oxford: Oxford University Press.

Shome, P. (1999) 'Taxation in Latin America: Structural Trends and Impact of Administration', IMF Working Paper WP/99/19, IMF, Washington, DC.

Slemrod, J. (1990) 'Optimal Taxation and Optimal Tax Systems', Fournal of Economic Perspectives 4(1): 157-78.

Slemrod, J. (2000) 'The Labyrinth of Capital Gains Tax Policy: A Guide for the Perplexed', Fournal of Economic Literature 38(3): 657-9.

Sørensen, P.B. (1988) 'Wealth Taxation, Income Taxation, and Saving', Blue Mimeo 163, University of Copenhagen, Institute of Economics.

Sørensen, P.B. (1993) 'Recent Tax Reform Experiments in Scandinavia', in L. Stetting, K.E. Svendsen and E. Yngaard (eds) Global Change and Transformation (pp. 357-76). Copenhagen: Munksgaard International Publishers.

Sørensen, P.B. (1998a) 'Recent Innovations in Nordic Tax Policy: From the Global Income Tax to the Dual Income Tax', in P.B. Sørensen (ed.) Tax Policy in the Nordic Countries (pp. 1-27). London: Macmillan.

Sørensen, P.B. (ed.) (1998b) Tax Policy in Nordic Countries. Basingstoke: Macmillan.

Steinmo, S. (2003) 'The Evolution of Policy Ideas: Tax Policy in the 20th Century', British fournal of Politics and International Relations 5(2): 206-36.

Stephens, R. (1993) 'Radical Tax Reform in New Zealand', Fiscal Studies 14(3): 45-63.

Stotsky, J. (1995) 'Summary of IMF Policy Advice', in P. Shome (ed.) Tax Policy Handbook (pp. 279-84). Washington, DC: International Monetary Fund.

Summers, L., Gruber, J. and Vergara, R. (1993) 'Taxation and the Structure of Labor Markets: The Case of Corporatism', The Quarterly Fournal of Economics 108(2): $385-411$. 
Swank, D. (1998) 'Funding the Welfare State: Globalization and the Taxation of Business in Advanced Market Economies', Political Studies 46(4): 671-92.

Swank, D. (2003) 'Tax Policy in an Era of Internationalization: An Assessment of a Conditional Diffusion Model of the Spread of Neoliberalism', paper presented at the International Diffusion of Political and Economic Liberalization Conference, Weatherhead Center for International Affairs, Harvard University, 3-4 October.

Swank, D. and Steinmo, S. (2002) 'The New Political Economy of Taxation in Advanced Capitalist Democracies', American Journal of Political Science 46(3): 642-55.

Tanzi, V. and Zee, H. (2000) 'Tax Policy for Emerging Markets: Developing Countries', National Tax Fournal 53(2): 299-322.

Van den Noord, P. (2000) 'The Tax System in Norway: Past Reforms and Future Challenges', OECD Economics Department Working Papers No. 244, OECD, Paris.

Wilensky, H. (2002) Rich Democracies: Political Economy, Public Policy, and Peformance. Berkeley: University of California Press.

World Bank (2003) World Development Indicators. Washington, DC: World Bank.

RÉS UMÉ

\section{La Mondialisation, les Idéals de la Réforme Fiscale et le Financement de la Politique Sociale}

Cet article analyse des types de réforme des impôts sur le revenu pendant les derniers 25 ans, et se concentre principalement - mais pas exclusivement - sur les pays qui appartiennent à l'Organisation de Coopération et de Développement économiques (l'OCDE). L'analyse fournit des leçons utiles sur le rôle des idées dans la réforme de la politique générale et le rôle des impôts sur le revenu dans l'accomplissement de résultats de politique sociale. L'article montre qu'il y avait deux modèles concurrents de réforme des impôts sur le revenu - la taxation 'compréhensive' et l'imposition 'double' sur le revenu - et que cette dernière avait plus de succès. La raison provient des contraintes structurales devant lesquelles les décideurs se trouvent. La taxation de beaucoup de sortes de revenus du capital coûte cher, et cela donne une forte motivation à baisser les taux d'imposition. Au même temps, la grande charge fiscale sur le travail donne une forte motivation à maintenir les taux marginaux d'imposition supérieurs sur les revenus du travail à un niveau élevé. Ces contraintes incompatibles indiquent des programmes distinctifs de taux d'imposition pour les revenus du capital et les revenus du travail - un trait distinctif de l'imposition double sur le revenu. L'analyse a des implications simples pour le rôle des impôts sur le revenu à atteindre des résultats de politique sociale. Premièrement, la taxation progressive sur le revenu du capital est gravement contrainte par des coûts élevés, mais si les décideurs sont prêts à séparer les impôts sur le revenu du capital des impôts sur le revenu du travail, ils peuvent utiliser les impôts sur le revenu afin de réduire la charge fiscale sur les salaires bas. Deuxièmement, les impôts dégressifs (les impôts indirects et les contributions à l'aide sociale) ne mènent pas forcément plus aux dépenses sociales élevées que les impôts sur le revenu - surtout parce qu'un taux élevé d'imposition sur le revenu ne suppose pas automatiquement une imposition élevée sur le revenu du capital. 


\section{La Globalización, los Ideales de la Reforma Fiscal y la Financiación de la Politica Social}

Este artículo examina las pautas de la reforma del impuesto sobre la renta durante los últimos 25 años, enfocándose principalmente - pero no exclusivamente - en los países de la Organización para la Cooperación y el Desarrollo Económicos (la OCDE). El análisis ofrece lecciones útiles sobre el papel de las ideas en la reforma de las políticas, y el papel del impuesto sobre la renta para lograr resultados de política social. El artículo muestra que había dos modelos competidores de reforma del impuesto sobre la renta - los impuestos «integrales» y los impuestos «dobles»-y que el último tuvo más éxito. La razón se encuentra en las limitaciones estructurales que las personas que formulan las políticas enfrentan. Los impuestos sobre muchos tipos de rentas derivadas de capitales cuestan mucho, y a consecuencia de esto hay fuertes incentivos para bajar las tasas impositivas. Al mismo tiempo, la gran carga fiscal sobre el trabajo da fuertes incentivos para mantener las tasas impositivas marginales superiores sobre la renta del trabajo a nivel alto. Estas presiones opuestas indican programas diferentes de tasas impositivas para la renta de capitales y la renta del trabajo - como es característico de los impuestos dobles sobre la renta. El análisis tiene consecuencias sencillas para el papel de los impuestos sobre la renta en la consecución de resultados de política social. En primer lugar, los impuestos progresivos sobre la renta de capitales se encuentran muy constreñidos por los gastos altos. Sin embargo, si las personas que formulan las políticas están dispuestas a separar los impuestos sobre la renta de capitales de los impuestos sobre la renta del trabajo, pueden utilizar los impuestos sobre la renta para rebajar la carga fiscal sobre los sueldos bajos. En segundo lugar, los impuestos 'regresivos' (los impuestos indirectos y las cotizaciones) no son forzosamente más propicios para los altos gastos sociales que los impuestos sobre la renta, precisamente porque un nivel alto de impuestos sobre la renta no implica automáticamente un nivel alto de impuestos sobre la renta de capitales.

\section{BIOGRAPHICAL NOTE}

STEFfen GANGHOF is a political scientist and Research Fellow at the Max Planck Institute for the Study of Societies, Cologne, Germany. His research interests are in political economy and comparative political institutions. His articles have appeared in the Swiss Political Science Review and the Australian fournal of Political Science, among others. He is the author of a book on the politics of tax reform in Germany and coeditor of a book on analytical approaches to the German political system (both published in German by Campus Verlag). He recently completed a monograph on the comparative political economy of income taxation, which will be published by ECPR Press. Please address correspondence to: Research Fellow Steffen Ganghof, MaxPlanck-Institut für Gesellschaftsforschung, Paulstr. 3, D-50676 Köln, Germany. [email: ganghof@mpi-fg-koeln.mpg.de] 